\title{
In Search of Stylistic Idiom - Music to the Central-European Cartoons Krtek and Reksio
}

\author{
Katarzyna Babulewicz
}

\begin{abstract}
Already in the 1960s Zofia Lissa, a pioneer of Polish research on the aesthetics of film music, in her monumental work pointed a distinction of the music composed for the animated films - "Principles of compositional techniques are slightly different for it than for feature films [...]". ${ }^{1}$ Researcher enumerated the following reasons for this speciall situation, among others: "short time of the movie (which provides the ability to use classical compositional techniques), fantastic visual layer of the cartoon (can be combined with unrealistic sounds, especially music), the fact, that here music is the only element derived from the real world (serves to make pictures seem real), and the artificiality of the image - it allows its closer relationship with the music." Although it's been more than half of a century since these preliminary observations were made, the issue of music in the animated film still does not catch the attention of the researchers - not only on the basis of Polish musicology, but in general. In 2005, Daniel Goldmark stated that there has been a lack of a "critical work about music in animated films."

This paper is an attempt to create a framework for the comparative analysis regarding the music to the European cartoons for children produced before 1990. The scope of the described framework is to prove the very existence of musical idiosyncrasy in such cartoons, and, if it's possible, to classify the composers according to the aesthetic, technical and cultural criteria (e.g., the traditionally concerned division into the Eastern and Western cultural zone). ${ }^{4}$ The framework includes the methodology of the cartoon
\end{abstract}

\footnotetext{
Zofia Lissa, Estetyka muzyki filmowej (Kraków: Polskie Wydawnictwo Muzyczne, 1964), 375.

Ibidem, 375.

3 Daniel Goldmark, Tunes for 'Toons. Music and the Hollywood Cartoon (Berkeley: University of California Press, 2005), 3, from: Anna G. Piotrowska, O muzyce i filmie. Wprowadzenie do muzykologii filmowej (Kraków: Musica Iagellonica, 2014), 28.

4 It is the aim of the future PhD. by the Author - intended to be a monograph of the European music to the cartoons produced before 1990 (before the perestroika in the Soviet Union).
} 
soundtrack analysis. In such a situation it seems to be useful to combine musicological approach with some elements of film studies, cultural studies, history, sociology etc. For interdisciplinary approach stands words of Iwona Sowińska (spoken in reference to the film in general): "Thinking about the special, the frontier phenomenon of film music, it is impossible to deal only with the notes." 5 The main object of analysis are, therefore, films with its soundtracks. Score may be used, but only auxiliary.

As for the methodology, the most appropriate tool seems to be the method of descriptive analysis by Kathryn Kalinak - the method consisting in describing representative parts of the film along with accompanying music. ${ }^{6}$ This method is used by many researchers. It allows to appreciate the element of original music in the film and to associate its style with general tendencies of the epoch.

I decided to focus on two cartoon series for children: the Czechoslovakian Krtek (The Mole) and Polish Reksio. The former was aired between 1957 and 2002 whereas the latter between 1967 and 1990. All the episodes of Krtek were directed by Zdeněk Miler and the series was produced by the film studio Bratři v triku. The episodes of Krtek vary in length taking from 5 to 30 minutes (the longest episodes were produced in the late 1980s, and the first one took 13 minutes). ${ }^{7}$ The main character, the Mole, does not speak (very sparingly he uses single words such as "ach jo", "ahoj" or, in one episode, "chamomilla”). Instead, he cries of joy, surprise or despair. The Mole lives in a forest and has many animal neighbors e.g., frogs, hedgehog, owl and various birds. Its best friend is perhaps a Mouse. The Mole is a bold character, curious about the surrounding world and eager to help others. The titles of the particular episodes typically consist of the name of the main protagonist and a noun of human origin (e.g., The Mole and the Umbrella, The Mole and the Bulldozer or The Mole and the Matchbox). Some, however, refer to a social role (e.g., The Mole as a Gardener; The Mole as a Watchmaker), a place to visit (e.g., The Mole in the Desert; The Mole in the City) or another character (e.g., The Mole and the Hedgehog).

Polish Reksio was developed in the Studio Filmów Rysunkowych in Bielsko-Biała. Over the years among its directors were: Lechosław Marszałek, Józef Ćwiertnia, Edward Wątor, Marian Cholerek, Romuald Kłys, Halina Filek-Marszałek and Ryszard Lepióra. As in the case of Krtek, it is a silent cartoon series. Its title hero is a pied mongrel living in a country. Reksio is bold and faithful to his master and friends. His surroundings comprise mainly the yard and the kennel to protect, but in fact are broader (e.g., Reksio is a friend of the brown dog and is apparently in love with a bitch that resembles the female character from Walt Disney's The Lady and the Tramp; sometimes he goes for an outside trip). In several episodes Reksio plays a role of fireman, therapist or teacher. His

\footnotetext{
Iwona Sowińska, Polska muzyka filmowa 1945-1968 (Katowice: Wydawnictwo Uniwersytetu Śląskiego 2006), 11.

6 Piotrowska, O muzyce i filmie, 35.

7 The first episode in the series entitled How the Mole got its Trousers (Jak Krtek ke kalhotkám prìsel) differs from all other because the characters speak. The Mole looks different, too.
} 
adventures often involve external characters, too (Reksio and the Sausage Dog; Reksio and the UFO; Reksio and the Cricket).

Regarding the musical background, Krtek is more heterogeneous than Reksio, because over the years it was provided with music by many composers, for instance Jaroslav Krrička, ${ }^{8}$ William Bukový, Miloš Vacek and Vadim Petrov. In the case of Reksio as many as 59 episodes (of total 65) are the work of just one man - Zenon Kowalowski; they are all preceded with the same funny opening credits. The music to the first six episodes of the series is by Tadeusz Kański, Bogumił Pasternak, Waldemar Kazanecki, and Adam Markiewicz.

For the sake of the credibility of comparison I decided to analyze only those episodes of Reksio and Krtek that are similar with regard to their content and scenery.

\section{The Mole as a Painter (Krtek malírem) - music by Miloš Vacek}

The beginning of this episode is typical of the entire series: the Mole leaves its heap to roam around the forest looking for adventures. This time he is surprised because the entrance of the heap turns out to be surrounded by multiple cans of paint. The mood of surprise is reflected in short bassoon motifs that are provided with grace notes and dispersed in the sound space. When the Mole curiously studies the vessels with mysterious liquid these motifs seem to stand for "testing". Then a fox appears ready to devour our hero. Its entry is accompanied with a sinister laugh. The fox is provided with its own theme. It is an aggressive, syncopated theme for trumpet and percussion, consisting of short motifs separated with pauses (they form a chromatic sequence). It resembles the so called figures of horror frequently used in the 19th century in the opera and program music. The timbre of the solo instrument corresponds with the surroundings (metal cans). The subsequent chase is full of the reminiscences of the "fox theme". However, when the Mole fells into the can of red paint (in the end, it also fells), the fox theme is replaced with some effects imitating the sound of the flowing paint. The fox escapes after Mole, emerging from the can, scares it with its specter-like appearance. The Mole fancies playing a ghost and its "spooky" gestures are accompanied with the musical motifs similar to the old rhetorical figures (the paranormal activity illustrated with e.g., tremolando of the synthesizer). The Mole scares the mouse, too. But having realized what happened, he bursts with a shrill laugh (treble flute and the highest notes in the piano). Then the Mole gets the idea to paint the mouse with vivid colors and each successive stroke of its brush is perfectly rendered as the short piano glissando (in the highest register of the piano). The successive layers of that camouflage are accompanied by the closed musical phrases. The bassoon plays a lively and grotesque, quasi-Shostakovich polka in $2 / 4$ meter and the

8 He composed the music to the first episode in the series. Stylistically, it resembles the symphonic soundtracks to the contemporary cartoons produced in the Soviet Union by I Dunajewskij, A. Aleksandrow or A. Wolkonskij. 
sequence of the intervals "deconstructs" the tonal harmony reflecting the "creepy humor" of the Mole. The polka theme alternates with the squeaky "mouse theme" (the mouse apparently enjoys its new appearance). Then, it is interrupted with a flute sound - the birds sing and the fox sneaks to their nest (a shortened repetition of the "fox theme"). However, the Mole and mouse drive the fox off with their aggressively pied appearance (the fly of the fox is accompanied by its theme). Consequently, the birds talk to their rescuers and decide to have themselves painted (dialogue of the flute and clarinet).

The musical background of the process of repainting differs to the previous themes, as it is a wide-phrase melody whistled to the discreet accompaniment of the percussion. Merry and fully tonal, it seems to refer to the labor songs. ${ }^{9}$ The birds fly away (flute theme imitating their twitter), yet many more animals - among others frogs hedgehog, squirrel and various birds - want to change their color. The process of painting is therefore intensified, so more instruments is involved. Initially, the electric guitar solo is played, but it is finally replaced with harmonica solo when a hare is painted to resemble a tiger. That fashion show is almost carnival-like with regard to the related soundtrack (high notes on the trumpet with the guitar accompaniment). With the appearance of the Mole the bassoon and bird motifs are once again played. The Mole leads the painted animals against the fox hiding behind a cut tree (the "fox theme" made more rough by means of the "alarming" sounds of the synthesizer). The night falls. After the brief introduction the optimistic "painting theme" is played once again - this time some plants are painted. The dawn is indicated with the "fashion show theme" (French horn solo). The fox, hidden in the tree hollow, cautiously looks out (a syncopated half-tone cadence on trumpet and several sounds of electric guitar) illustrating how the fox is terrified with a sudden change of the surroundings). The animals laugh at the fox (high notes in flute resembling the singing birds) and discuss which strategy to adopt (the separate sounds and effects produced with synthesizer). The hare digs into fox's hideout and it flees scared by other animals (the surrealist atmosphere stems from electronic effects), which makes all the "wights" laugh (high notes in flute).

$9 \quad$ This kind of association seems to be the more empowered when we take into account the fact that the composer of the music for this episode - Miloš Vacek actually had mass songs in his œuvre, see Československý hudební slovník osob a institucí, red. Gracian Černušák, Bohumír Štědroň, Zdenko Nováček, Svazek druhý (Praha: SHN, 1965), 828-829. 
Fig. 1: The Mole as a Painter (Krtek malírem)

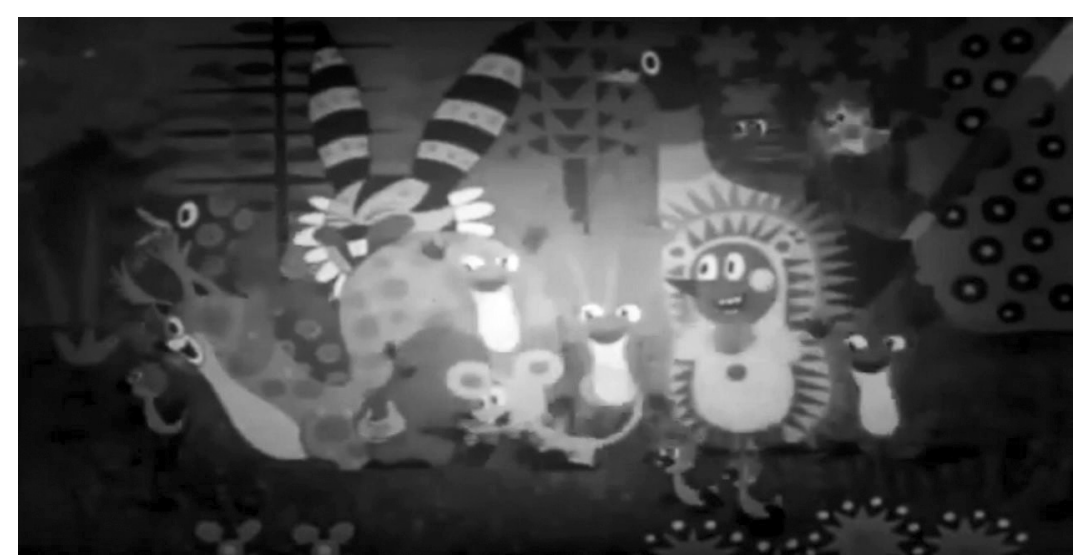

But in the end the rain washes the paint out (which is imitated by the very characteristic fuzzy sound fabric made with synthesizer and flute and consisting of the network of falling phrases). Fortunately, the dangerous fox fled and the animals dance triumphal waltz in a circle. The waltz is humorous owing to the use of the quite "heavy" instruments that are not typical of that dance - here, the trumpet solo seems not to be coincidental, because in the analyzed episode it is the core of the theme of the defeated fox.

The very specific feature of The Mole as a Painter is the use of leitmotifs ${ }^{10}$ - either independently or as a part of more complex musical structures. That reflects the crucial points of the scenario and makes it more dynamic - appearing together with the particular characters; (the composer, Miloš Vacek, used them again in some other episodes of Krtek). As a result, the music to Krtek is full of traditional musical topoi such as bird songs, figures of horror, the labor songs or the musical visions of the underworld, which makes it suggestive and almost literal in reception. However, the use of electronic instruments and avant-garde motifs ${ }^{11}$ is also significant. The timbre of the instruments plays important role, too. Stylistically, the entire texture is hardly uniform as the musical material frequently changes and therefore the quite "flat" segments alternate with the strong themes referring clearly to the specific dances or songs.

10 Zofia Lissa points out that while in the the opera leitmotifs has not only informative function, but they also create form, in the film the further integration of the whole work is entrusted to them - not only in terms of sound. Lissa, Estetyka muzyki filmowej, 306.

11 As Zofia Lissa wrote in the 1960s: "The fact that in this genre [in cartoons] the experimental music, electronic and concrete, begins to play increasing role - tells us that some of this films already belong to the category of experimental films.” Lissa, Estetyka muzyki filmowej, 376. 


\section{Reksio as a painter (Reksio malarz $\left.{ }^{12}\right)$ - music by Zenon Kowalowski}

Just as the Mole, Reksio turns out to be a gifted painter. But his artistic adventure partially crosses the boundary of the human world and is more narrative, namely, the analyzed episode involves many secondary heroes and is in fact a series of events taking place in two worlds: the human and the animal. Here, in contrast to Krtek malírem the musical phrases resemble the classical music because they consist of regular sentences or even periods that are repeated, arranged in sequences or developed as variations. Despite the fact that the particular themes appear several times accompanying the plot, they are to a great extent an independent counterpoint to the presented events. The leitmotifs fixed to the particular characters are almost nonexistent. Instead, the composer strives for showing the change of mood by means of referring to the traditional musical idioms (e.g., pastoral, heroic or military). Kowalowski tends to avoid using sound effects to illustrate the action. Sometimes he even uses a rebours effects (a dynamic chase illustrated with a silence). Generally, his music is tonal and chamber, devoid of sonoristic techniques.

Reksio as a Painter starts from the scene showing the dog dreaming in his kennel, which is typical of the whole series. The music underscores the optimistic atmosphere of the dawn (a simple phrase in major key played on the classical guitar to the subtle accompaniment of the strings con sordino and with a brief flute motif). Reksio yawns and the repetition of the phrase above takes place. However, it is interrupted, because the dog suddenly hears the sound of the heels: a man passes behind the fence carrying a picture under his arm. This is reflected in the music (its rhythm becomes more complex, the guitar ceases to play - strings tremolo resounds instead). The melody is still optimistic, but the change of the rhythm, cast and articulation make it denser; owing to the tremolo the surprise seems to be in the air.

Then, Reksio follows the painter and they reach an art gallery (an energetic march fragment in duple meter), but because dogs are not allowed to enter he must stay outside. Reksio looks through the window and sees the artist showing his picture to other people who apparently appreciate it. Our dog hero starts dreaming of such esteem (a traditional dream bubble together with a single sound of the guitar resembling the striking clock, and three accords on the bass guitar standing for the "fate motif").The flute plays a short motif similar to the previous march to the art gallery and Reksio is about to go home.

12 The analysis of that episode is an excerpt from the BA thesis of the Author (2013) prepared under the direction of dr hab. Magdalena Dziadek, cf. Katarzyna Babulewicz, Muzyka Zenona Kowalowskiego do wybranych odcinków serialu Reksio (Jagiellonian University in Kraków, 2013). 


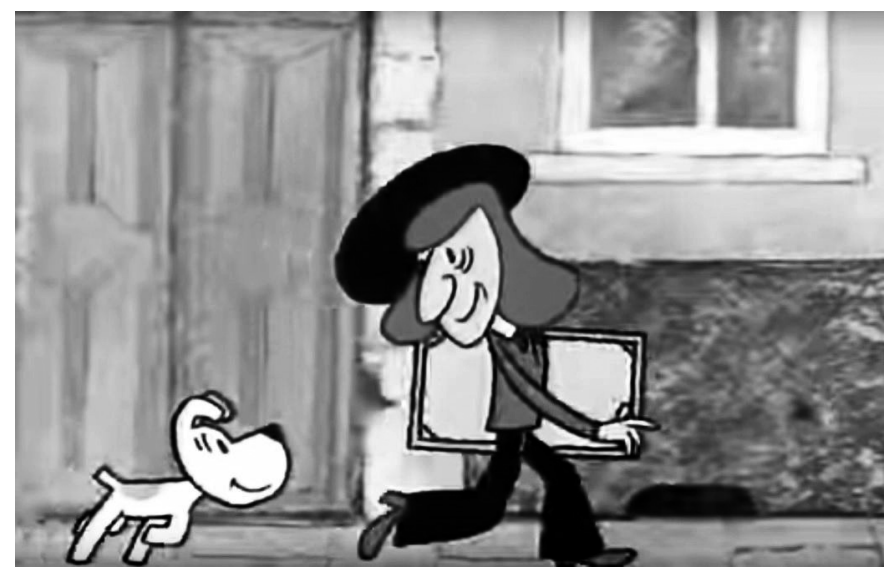

In the next scene little boys paint primitive graffiti on the wall. One of them scribbles, against the orthography, "Wacek jezd gópi" (Vaclav is stupid) and a caricature of a dog. Their mischiefs are illustrated by the infantile motif similar to a piano piece for beginners; it may recall also the sound of hurdy-gurdy due to the use of high notes on the glockenspiel. That fragment fluently turns into next by means of glissando (the effect used also in Krtek) of the glockenspiel and the solo flute (in the opposite direction); Reksio snarls at the mischievous boys to scare them and take their paints. His way home is merry (a dialogue of the flute and clarinet to the delicate accompaniment of the strings and bass guitar). Having returned to its yard, Reksio invites other animals to be his models. The composer depicts them by means of the music - taking into account their characters instead of the appearance. The first is a turkey (its "pompous" entry illustrated with major second and when it ruffles its feathers the flute plays the gamut). Then, a pig (bass clarinet and acoustic effects) and a hen (descending fourth sequence on the flute and clarinet) poses. Finally, a rooster appears. Its musical characteristics is more complex and reflects its belligerent and commanding nature (very fast cadences of the flute alternating with the single sound of the clarinet or double stopping of the flute and clarinet - it is all played with the accompaniment of the bass guitar that resembles a military fanfare due to use of repeated triton; when the rooster flexes its chest sharp bow strokes of the strings can be heard). Reksio decides to choose the rooster as the model and prepares itself for painting (the same fragment illustrated the dog hero taking its paints). The rooster waits standing on a box. It imagines that it wears a military uniform (a quasi-military trumpet solo being the repetition of the introduction to the whole series - even the key is the same). Such "musical recycling" is a typical policy of the composer who uses the main motif from the intro for further variations and stylistic transfigurations. In the meantime, the other cock appears. The low trill of the bass clarinet sounds and in response to it bass guitar plays the triton syncopated "rooster motif". Then, the noisy cock fight breaks out, 
that struggle being perhaps the most violent fragment of the entire episode (the trumpet solo - a warlike instrument - repeats two motifs imitating the fighting cocks: each of those motifs is a clash of two quavers and a quarter note). Reksio is so busy painting that it reacts when instead of the warriors one can see a cloud of dust (it is reflected in the music: only the chaotic pieces of the previous motifs resonate). Reksio separates the roosters from each other, but one of them has already lost its feathers. Some order is brought into the musical chaos i.e. only those figures are preserved that mock heroic motifs (the composer deconstructs the timbre of the instruments lowering their pitch). As a result, the painting remains unfinished. Reksio puts it on the easel next to its kennel and goes to bed (a lyrical sequence resembling a lullaby). But it starts raining. To the Reksio's despair, the canvas falls to the wet ground and turns into unrecognizable stain (the vibraphone plays the quarter note leap).

The dawn is announced by four already introduced measures (their dance-like rhythm accompanied the eccentric artist in beret). And indeed that artist appears. He finds the destroyed painting and, unexpectedly, is delighted with it (he thinks that Reksio created an abstract work and decides to take it to the art gallery). Again, Reksio and the painter walk the street - this time it is the human who ensues the dog; the music is the same as in the case of their former walk and when they enter the art gallery a mysterious hand squashes the "no dogs allowed" plate to let Reksio in (a rattling percussion). In other words, Reksio was recognized as an artist. He is given a diploma and is even tempted to sell the canvas (instead of the money it chooses sausage).

The whole situation is observed by a shady character. According to Włodzimierz Propp, it is a typical antagonist who wants to enrich himself selling Reksio's paintings. The change of the music is a harbinger of the incoming events, as it becomes less regular and is more strictly subordinated to the particular events (which are faster and faster). The villain is then characterized with the dotted rhythm of the bass guitar, tremolo of the bass clarinet, rattling percussion, sharp strokes of the bow in the strings (or by exposing triton). Reksio is abducted and imprisoned in a cellar full of blank canvases. The villain gives him an order to paint and shuts the door. Reksio is first dejected but quickly gets over the situation and invents the escape plan. (Zofia Lissa wrtites: "It is true that the music would not give the content of someone's decision, but it may signal it by its means." ${ }^{13}$ ) Hence, the next musical sequence is regular and optimistic in mood (a flute sequence in major key). Reksio starts painting (the third repetition of the "painting motif") a very realistic image of the prison window with bars ripped out. Having hung it on the wall, Reksio shouts "Haha!". The villain returns to discover that his victim ran away through the window. Thanks to that trick, he faints and Reksio escapes - this time for real (the villain theme with the uneasy play of strings and bass guitar is brief and the moment of fainting is reflected by the cease of the play of the strings, and the falling half-tone sequence of the clarinet and the stoke of the percussion; the rising half-tone sequence of the clarinet announces the opportunity to escape).

13 Lissa, Estetyka muzyki filmowej, 224. 
Reksio runs hurriedly along the street (his fast pace is rendered with a light musical texture, frullato of the flute and octave leaps). But the villain wakes up in the cellar and starts chasing the dog (an aggressive repeated trill of the bass clarinet together with the single, repeated sounds of the bass guitar). However, Reksio prepares another trap image near its kennel (once again, trill of the bass clarinet together with the sounds of the bass guitar). The process of painting is accompanied by the short phrases of the clarinet (half-tone) and single sounds of the flute (minor third) resembling an alarm signal. They contain also some element of surprise because one cannot see what exactly Reksio paints. The dog hides and the villain stands next to his kennel. He looks around (various percussion instruments; the sequence is irregular - pianissimo turns into mezzo-forte and then into piano: therefore, the loud tutti in the half-tone triplets is so contrastive). The mentioned tutti is an illustration to the scene in which Reksio suddenly shows the villain the poster with a monster with the open jaws. The shady character screams and escapes. Yet he turns back from time to time and subsequently hits a lantern. In the coda of the whole episode the composer used the last phrase of the motif being a background of the first trip of Reksio to the art gallery. This time, nevertheless, it comprises a fourth played on vibraphone - perhaps it stands for a prize.

\section{The Mole in the Desert (Krtek na poušti, 1975) - music by Vadim Petrov}

Not all adventures of the Mole take place in the forest. The hero pays also visit to the nearby village ${ }^{14}$ and city ${ }^{15}$. He comes to a school to rescue the hedgehog. ${ }^{16}$ Once he visits the movie set. ${ }^{17}$ On the other hand, in the episode entitled The Mole in a Dream the protagonist finds a way to very modern household containing many devices resembling science-fiction movies (that particular episode, beneath the cartoon surface, is quite serious, as it analyzes the issue of the conflict between the nature and civilization and the impossibility of the return to the former). Twice the Mole takes a voyage to very exotic places. One of them is an uninhabited island ${ }^{18}$ (by means of the rocket), whereas the other is a desert.

How is it possible? It is a sheer luck: the Mole leaves his heap about the landing pad for helicopters. The Mole admires the flying machine to the sound of the "voyage theme" - that theme consists of optimistic, vivid and regular musical passages in duple meter clearly resembling the Czech folk music ${ }^{19}$ (especially due to the use of the accordion

14 See The Mole and the TV, 1970, dir. Z. Miler, mus. M. Vacek.

15 See np. The Mole in the Town, 1982, dir. Z. Miler, mus. V. Petrov.

16 See The Mole and the Hedgehog, 1970, dir. Z. Miler, mus. M. Vacek.

17 See The Mole as a Movie Star, 1988, dir. Z. Miler, mus. V. Petrov.

18 See The Mole and the Rocket, 1965, dir. Z. Miler, mus. Milan Kymlička.

19 In this case, the association of folk music is so similar with the considerations of Iwona Sowińska concerning the essence of folk music in films produced in PRL: "Regardless of the type of portrayed 
which is typical instrument of it). Its mood is underscored by virtue of the dotted rhythm and funny accompaniment of the bass guitar. Then, the theme is repeated in higher register and developed by the clarinet whereas the accordion part is repeated as refrain. The Mole discoveres the backpack under the helicopter and, just for fun, slips into its pocket. The automatic arm takes the backpack on board and the helicopter takes off. The "voyage theme" (together with the whirr of the engine) sounds in the background of the aerial view of the landscape, sea, port and, at last, the desert. The helicopter drops the back backpack on the parachute in order to supply the research station (one can see the tents, metal boxes, the wooden box with the inscription "expedition" and, perhaps, electric pylons or transmitters). Immediately after landing, the musical theme is replaced with the voices of the blowing wind (and of one device). The single sounds of the guitar and trills of the clarinet illustrate the surprise of the Mole, as the hero discovers that the station is abandoned. Here, the main adventure begins - together with the brand new musical background. The composer adapts the music to the Arabian style by the conventional means such as monotonous dynamics, the use of the Gypsy scale (with raised seconds), building the melody with the empty fifths of the woodwind instruments (flute, clarinet), as well as using the technique of double repetition of the phrases in octave imitation. Apart from that, the composer uses the so called bolero rhythmic formula in the accompaniment (which is of the Spanish and not the Arabian origin). The "desert theme" is played on the clarinet to the syncopated drum hits (the particular drums are differently tuned) resembling the complex African rhythms. The Mole wanders through the desert and the heat quickly exhausts him. The hero sees the water, but of course it is a mirage (the voices of the triangle and vibraphone - when the Mole is about to "drink" the triangle, guitar and vibraphone imitate the sound of the flowing water, yet the the mirage rapidly disperses and simultaneously the desert theme returns). At last, the Mole reaches the well but it turns out to be sand-filled and thus useless. It discovers also the tracks of multiple large animals. It decides to follow them (a succinct accompaniment of the percussion - the desert is dry). From the top of a sand dune the Mole observes the inhabitants of the desert: a monkey, zebra, camel, giraffe, ostrich and lion. The lion is obviously the one which stands above all other animals because it sleeps on the bank of the small pool protecting the miserable amount of water, whereas its "subjects" wait for their turn. At the sight of wild animals the orchestration of the "desert theme" undergoes a change and is no longer exotic and mysterious, but sounds as a threat (heavy electric guitar solo and short sounds of the clarinet). However, the Mole seems to be unaware of a danger. He waves his hands, trustfully approaches and starts drinking the water. The angry lion drives him off with a snarl. The Mole returns to the sand-up well and come to the idea to fix it (the brainwave illustrated with the clarinet trill). He puts his ear to the ground to check if the water still flows underneath. It occurs that the well is to mend. Luckily, the Mole has his faithful shovel. The musical background becomes more energetic

environment the folk music was always associated with free time. It meant spontaneous joy and a sense of familiarity." Sowińska, Polska muzyka filmowa 1945-1968, 77. 
due to the bolero-like accompaniment. The melody is led, alternately, by the flute and clarinet to the guitar ostinato (descending half-tones); it resembles an exotic dance. Of course, the Mole does not dance but work pretty hard.

Fig. 3: The Mole in the Desert (Krtek na poušti)

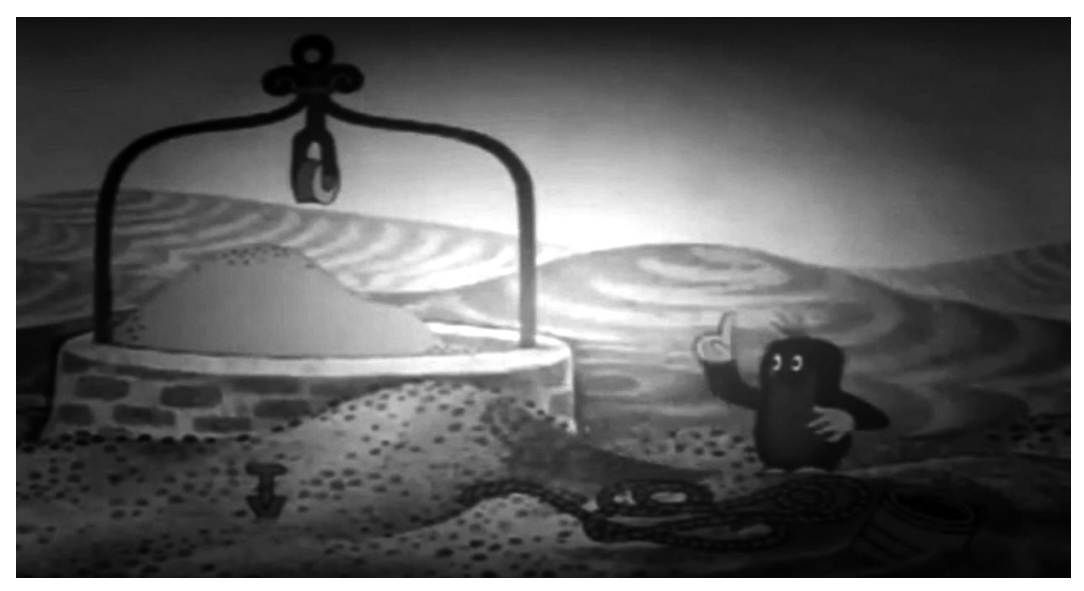

Owing to his skills in digging underground tunnels, he briskly removes all the sand blocking the well and reaches even deeper layers of the soil. Then suddenly someone fills the well up with sand again (it is an elephant: its direct appearance is preceded with new, much slower melody played on the trombone). The Mole convinces the elephant to remove the sand with its trunk (the mechanical nature of that work is reflected in the octave imitation of the "Arabian motifs"). When it is too deep for the elephant to use the proboscis, the giraffe starts working instead (quasi-dance theme). Finally, the well starts to fill up with water. The Mole is raised by it and the giraffe recovers him with a bucket. All the animals had already gathered around the well to drink water together (an exotic dance, but this time the orchestration is enhanced with the trombone because the elephant is also present). The Mole hears the helicopter (and the swinging, European melody of the accordion returns). It runs to slip into the backpack and the grateful animals wave to bid him farewell. The noble Mole, which frequently helps the forest animals to get through multiple troubles in one piece, this time brought help to the inhabitants of the desert. Perhaps he has shared the high ideal of equality of all the citizens of the world.

The analyzed episode is not only clear with regard to the ideological meaning (the solidarity, unity and collaboration enable the people to achieve the common goal) but its musical structure is simple. It is a reprise structure ABA coherent with the plot. The A sequence reflects the journey to and from the desert. The B sequence pertains to the events in the desert. However, that symmetry regards not only the entire framework, but also the internal musical sequences which are periodical and regular musical phrases developed with the classical techniques (repetition, contrapuntal dialogue of the motifs, 
variations). The composer has adopted almost the same strategy as Zenon Kowalowski in the Reksio as a Painter, because in both cases the music is largely independent to the shown events (the good example is the fact that the moment when the water spurts from the well is not reflected in the soundtrack). In other words, the music is intended to illustrate the mood invoked by the visual images. Hence, the helicopter flight is connected with typical Czech popular music whereas the desert is accompanied by the quasi-Spanish and quasi-Arabian motifs. The musical imitation is also sparing (the voice of the elephant and the shouts of joy when the well is fixed).

\section{Reksio as a Mountaineer (Reksio taternik, 1972) - music by Zenon Kowalowski}

Just like the Mole, Reksio sometimes goes for various trips. He visits the city, ${ }^{20}$ the local zoo, ${ }^{21}$ dog heritage park and even the museum. ${ }^{22} \mathrm{He}$ spends the holidays with his master, ${ }^{23}$ takes a dream voyage to an uninhabited island ${ }^{24}$ and real voyage to the outer space. ${ }^{25}$ One day he enters the mountain trail.

The analyzed episode begins at dawn. Reksio has not woken up yet, but the previous fragment showing the sunrise over the mountains is an unambiguous sign that the whole plot will be connected with the Tatras. The flute intonates a melody typical for the Podhale ${ }^{26}$ region and resembling the sound of shepherd's pipe. Reksio snores but the wanderer (who appears only in this episode) with a backpack whistles to wake him up. The noise makes other people angry (it is still an early morning and they want to sleep) and they throw pots and flower pots at Reksio (the chaotic sounds of wind instruments and percussion; after that humorous intermezzo the lyrical "mountain trip" theme returns). In the next scene the dog and the wanderer follow the mountain trail. Here, the music is different, but it refers to the folklore of the Podhale even more clearly (the melody is played on the bagpipes to the fifth notes of the strings as an accompaniment; it is once again a brilliant self-parody of the initial theme of the series - this time humorous, as it is based on the specific acoustic scale typical of the Podhale music). The first obstacle for the tourists is a ram whose vile character is illustrated with sharp strokes of the bow (even before it appears). Once confronted it looks daggers at the wanderers and the melody ceases to sound. Reksio and the tourist try to pass the ram (the use of the single sounds of the windpipe instruments and percussion underscores the danger). Their success is

\footnotetext{
20 See Reksio as a Benefactor, 1970, dir. L. Marszałek, mus. A. Markiewicz.

22 See Reksio as a Guide, 1977, dir. L. Marszałek, mus. Z. Kowalowski (during the visit in the museum one can hear the baroque music)

23 See Reksio as a Wanderer, 1972, rez. J. Ćwiertnia, mus. Z. Kowalowski.

24 See Reksio as a Castaway, 1973, dir. L. Marszałek, mus. Z. Kowalowski.

25 See Reksio as an Astronaut, 1972, dir. L. Marszałek, mus. Z. Kowalowski.

26 The Polish Tatra Highlands.
} 
temporary, but for the time being they may wander further their way (a short sequence resembling a highland march - the fifth notes of the flute to the rhythmical accompaniment of the percussion). Together they reach a mountain stream. Here, the tourist falls into it and starts drowning. The sound of flowing water is mixed with the short, dramatic dialogues of the flute with the oboe and clarinet (with the additional tremolando of the strings - a conventional horror figure). Reksio cannot save the man alone so he runs to the ram looking for help. The ram phlegmatically chews the grass (yet its sight is dangerous owing to the syncopated trumpet motifs based of fifths). After the alarming trills the ram starts chasing Reksio instead of answering its beggings, but in its fury it hits the tourist and subsequently throws it out the stream saving his life. The unconscious mountaineer lies on his back (which is a bad omen - a descending sequence of the repeated half-tones of the synthesizer). Fortunately, Reksio knows how to resuscitate the man and he comes around (short, low sound of the clarinet). In the next scene the "mountain trip theme" returns and the sound of the bagpipes accompanies the further steps of Reksio and the tourist. They are much higher now and their trail has become steep, rocky and snowy. Moreover, they are unaware of the fact that they are followed by the ram. Suddenly the mountaineer loses the balance and starts sliding down the icy slope (that particular fragment is close to the stylistics typical of Disney's ${ }^{27}$ cartoons: the alarming sounds of the trumpet and percussion precede the descending sequence of sounds of the xylophone; the synthesizer is also present here). When the man reaches the part of the trail still uncovered with ice the clarinet trill announces the ram waiting for its prey. The man tries to escape but he chooses exactly the same way as before and the Mickey Mouse effect returns (his moves are synchronized with the ascending progression of the trumpet and, when the man reaches somewhat higher ground - oboe). The ram is now about to charge (its war theme by the trumpet) whereas the mountaineer almost reached Reksio that gives him its paw (double frullato of the oboe). The man once again falls down (to the precise windpipes glissando and descending tones of the xylophone) and bounces off the horns of the ram, which, however, allows him to pass the icy path. The next stage of the trip is accompanied by the clarinet melody (a variation of the "mountain trip" theme, this time devoided of the strings playing fifths). The trail requires the tourists to use the ladder and climb to the higher rocky terrace. The mountaineer helps Reksio up for the ladder steps are slippery (as early as here the syncopated fifths of the trumpet sound). Reksio marches alone for a moment (the oboe sounds) but quickly retreats because the ram blocks the path above the ladder (less heroic clarinet can be heard). The man who does not see the ram yet, laughs and decides to climb alone (a humorous passage full of the repeated notes in the high register of the flute) but he is also forced to flee and fells from the terrace (a strike of the percussion; the light motif of the flute is now taken by the trumpet). The mountaineer invents a way to outwit the antagonist. The music plays accelerando when he

Zofia Lissa, analyzing Disney's music, which is completely synchronized with the image makes the following observation: "[...] its perfect adequacy to the picture already has itself something of the world of fairy tales, fantasy, unreality." Lissa, Estetyka muzyki filmowej, 375. 
finds a bough, puts its hat on it and hurls it as if he use a mountain ring (whose sound is audible). It provokes the ram to charge straightforward up to the icy slope where it cannot stop and slides down. The friends are then safe (a short fragment referring more to the entire series than to the particular episode) and wander while the flute plays the idyllic melody (to the accompaniment of high register of the piano - the damper pedal is used). The clarinet trills suggest that not all the obstacles were overcome. There is a deep crack in the trail and the tourist falls into it. Reksio panics. A dynamic fragment (consisting of the repeated half-tone of the clarinet that bears partial resemblance to the emergency signal) alternates with the massive tutti (multiple instruments raise a clamor). Reksio runs for help to the chalet (the orchestra sounds very aggressive: no instrument is silent, the flute repeatedly plays a high note, then the flute and the trumpet make an ascending passage to stress the fact that the dog heads a mountain rescuer's house. But inside the music is very different: the rescuer sleeps like a log (snoring to the accompaniment of the piano ragtime, perhaps from the radio). Reksio successfully wakes him up imitating the sound of emergency alert. When they run together to help the tourist the dramatic musical chaos returns (the triols are worth noticing). Then the rescuer ignores the bleating of the ram and it pushes him to the same crack into which the victim fell. As a result Reksio is forced to rescue not only the tourist but also the professional rescuer. He is first angry at the ram. Then he wraps a rope around its horns, throws is loose end to the entrapped men (single tones of the flute), and provokes the ram to begin the chase (the charge theme). The ram angrily follows Reksio and finally hits the rock. In the meantime, it unintentionally pulls the men from the hole. The humorous music is a background of the scene in which the ram, the rescuer and the tourist recover from the sustained injuries and shock. Then Reksio shows the rescuer what happened and clearly stresses the role of his wit (stronger than muscles). The dog hero is awarded with the rescuer's cross. ${ }^{28}$ The final coda refers to the "mountain trip" but is almost devoided of the highland stylization (the traces of such stylization are still visible in the cadences; perhaps the composer found it more convenient to choose more "European" piece for the moral of the episode, because it seemed to be easier to grasp than more "uncouth" highland music.

With regard to the music, the analyzed episode is significant and very intriguing. First of all, Kowalowski closely adapted the music to the musical style typical of the Podhale (the melodies based of the "highland scale", using empty fifths in the accompaniment, the rhythm of the highland march, and the orchestration including bagpipes, fiddle, pipes and shepherd's bells). Apart from that, he made many fragments illustrating the particular events, especially falling and sliding down. Such solutions inevitably lead to the musical imitation of the movement of the characters. This time it was possible not only because of the choice of the mountainous terrain for a background, but also due to the fabular scheme involving the constant play between the protagonists and the "persecutor" (the ram). Therefore, the musical texture of that episode is very heterogeneous and comprises

28 Reksio helps various characters in most of the episodes. Even as an actor it plays the role of the rescuer dog saving the mountaineer. See Reksio aktor, 1972, dir. J. Ćwiertnia, mus. Z. Kowalowski. 
many smaller fragments of "local" use. Neither leitmotifs nor musical framework themes are used, but, once again, the composer "recycles" the music to the initial credits as a form of intelligent musical parody.

\section{The Mole and the Music (Krtek a muzika, 1974) - music by V. Petrov}

The fourteenth episode of Krtek has unusual beginning. The Mole, apparently relaxed, rests in his comfortable hole and listens to the music form the gramophone. He lies on his back with hands behind his head. Only due to the gentle swing of his leg we know that the Mole doesn't sleep. It turns out that the hero, like humans, enjoys the music hardly available in the forest (the piano ragtime in 2/4 meter to the subtle accompaniment of the percussion - the rhythm is provided with the tuba).

But the relax is interrupted by the mouse that rings the doorbell: the heart of the Mole leaps into its mouth. It turns out that it is blowing a gale outside. The mouse is pushed by the wind in and thrown at the opposite wall together with the gramophone (the final fragment of the ragtime is so deconstructed that it sounds like a screech, especially blended with the mourning sound of the wind). The Mole shuts the door (it is not easy) and discovers that his record is broken. He takes the useless fragments from the floor and sadly says "ach jo". In the next scene the depressed Mole sits on the top of its heap and the mouse tries to comfort him by bringing him various round objects which may replace the shattered record e.g. a button, a cap or a clock gear. However, the sound of the clarinet is now so cheerful that the spectators must suspect the Mole to take his loss too seriously ${ }^{29}$ (the ascending progression seems to perfectly match the musical narrative concerning a several-stage task). And indeed, the hero sees two red objects landing nearby (their appearance is underscored with the leap of the perfect fourth in the xylophone, which makes a cadence leading to the end of the current musical fragment in which the clarinet was a solo instrument). The new fragment starts from the fine and closed passage of the flute containing eight note triplets and the gruppetto. The Mole looks up and discovers that it is the bullfinch sitting on the tree that sings. Its concerto is short (it flies away in the middle of the repetition of the phrase in the progression - another instrument finishes it). When the bird sings, the red notes fall down to the ground. The Mole takes one of them and it turns out that one may ring it as if it were a bell. After the bullfinch, an owl performs (the melody is analogical to the bullfinch's aria with regard to the meter, key and dance character, and it cause the grey notes to fall down - according to the color of the singer's feathers). The next soloist is a blackbird, a professional violin player able to play fast triplet passages, glissandos and grace notes. The fourth singer is a hoopoe with a beautiful orange crest which plays the bagpipes (its passage is rustic and

\footnotetext{
This way composer avoided a situation that Michel Chion calls illusion of redundancy - according to the researcher, although the interaction of image and sound is based on synchronization, they should not unnecessarily duplicate each other. Piotrowska, $O$ muzyce i filmie, 45.
} 
folk-like). In that band a woodpecker is, of course, responsible only for the percussion. The above-mentioned concerto results in more colorful notes on the ground and the short optimistic motif having the function of a cadence (vibraphone + percussion). That particular passage is base on the melodic progression, which suggestively shows how rich is the bird "harvest": there are several heaps of notes, each one from other bird. The cadence seamlessly turns into the theme that can be heard after the shattering of the record up to the bird concerto. The Mole and the mouse collect the notes to their mugs and other vessels as if they collect the berries (a dialogue of the flute and violin - despite the fact that the motif is repeated, this time the orchestration changes in order to give the percussion more prominent role, perhaps in order to imitate more monotonous work). The music ceases to play for a moment when all the notes are collected and the Mole says triumphal "aha", because he knows exactly what to do. Now, the flute plays the already known prelude once again. The protagonists knead the notes in a bowl as a dough and roll it out. The Mole copes with the red whereas the mouse manages with the yellow ones (because the yellow notes were produced by the hoopoe, one can hear the sound of bagpipes now - there is no doubt that the change in orchestration was purposeful). Similarly, the act of cutting the musical dough by the Mole is accompanied by the flute (the bullfinch played it). Here comes the musical joke, namely, the Mole is tempted to taste the mysterious dough (instead of the flute the clarinet plays the alarming trill) and he does it. As a result, the Mole belches with a bell sound. The mouse brings new colorful balls (after the grey one the tube - the owl's property - is for a moment a leading instrument). The Mole and the mouse join the pieces of the musical dough together to create the gramophone record (the same musical passage introduced by the flute). The record turns out to be functional and for the third time the diegetic music sounds being the core of the "bird concerto". It is, nevertheless, in $3 / 4$ meter and resembles the waltz. The tones of the vibraphone subtly creates the mood. The joyful Mole dances.

The detailed analysis of that episode was intended to show how seriously the composer treated the music as a certain phenomenon and issue. According to that episode, listening to the music is a complex process. First, the noisy ragtime appears hardly consistent with the nature (perhaps it is a symbol of the civilization). After the accident, the recording must be reconstructed, but this time the "raw materials" are natural. The new record is then a better synthesis (the delighted Mole dances). Therefore, the shattering of the first record brings a positive change. It is not a coincidence that the composer used the waltz in the final scenes. The waltz has folk origins but in the European tradition it was commonly used as an illustration of the merry and serene opera scenes. In the musical literature it is often connected with the pristine nature (e.g., The Waltz of the Flowers by Tchaikovsky or The Blue Danube Waltz by Strauss). It is hardly a coincidence also that the title of the whole episode is The Mole and the Music and not, for instance, "The Mole Listens to the Birds" or "The Mole and the Gramophone". It suggests that the real topic of the episode is the evolution of the attitude of the main character towards the art of music (all moles can, in fact, hear very well). Initially the Mole seems to be very much assimilated with the culture (which is the highest product of the civilization - and the latter is hostile to 
the animal). But his mourning over the broken record is short. It may be easily replaced with the real music, the forest one. ${ }^{30}$

Regarding the musical texture, one should stress the fact that the three most important fragments (the ragtime, the "Mole at work" theme and the waltz) are very different to one another, but they are coherent and share the common motifs. Similar to The Mole in the Desert, the music is inseparable from the visual side of the cartoon. It was a small masterpiece of composition to render the voices of the birds with the musical language and make them one symphony. Simultaneously, the musical path is autonomous, which is reflected in the macro-form constructed according to the rules of musical composition, based on similarity and contrast.

\section{Reksio as a Singer (Reksio śpiewak, 1975) - music by Zenon Kowalowski}

Reksio is a domestic animal. Being a faithful friend, the guardian of the yard, and the defender of the weak, he seldom faces the threats of civilization. Perhaps it is because Reksio imitates the man and plays various human roles. In the particular episodes of the series he becomes an actor, fireman, magician, or even composer.

The episode entitled Reksio as a Singer has a typical starting point: the dog hero, quite sleepy, leaves his wooden kennel with pitched roof and looks in all directions as if he hardly know where to go. Finally, he merrily goes along the fence. The scene does not contain any clue regarding the future events, but is accompanied with a short musical fragment played by the electric guitar. It is not particularly memorable (even if regular) but is intended to build the tension - because it seems to precede something less opaque (a delicate suggestion that something is in the air is hidden in the flute trills in the end of the phrase). About the gate Reksio hears the horrible sound of the "murdered" violin. It follows the dissonance and finds out that the false notes come through the half-opened window. Reksio looks inside and discover that his master (a blond boy) practices the violin. Despite the fact he has a music stand and keeps the instrument properly (and the fact that he finds his play to be perfect), he knows nothing about playing correctly. When his fourth changes its pitch several times, Reksio howls it correctly (in other words, the dog

30 The Mole was also mourning over another gizmo i.e. the camera. But the hero quickly understood that instead of taking the photos it may draw the portraits of forest families. (See The Mole as a Photographer, 1975, dir. Z. Miler, mus. V. Petrov). The Mole usually is surprised by new inventions and tries to take care of them as of living animals (See e.g., The Mole and the Telephone, 1974, dir. Z. Miler, mus. V. Petrov). The civilization in the series is always something negative, either directly (See The Mole in the Town, 1982, dir. Z. Miler, mus. V. Petrov), or indirectly (as in the episode Krecik i telewizor, 1970, dir. Z. Miler, mus. M. Vacek, where the tv advertises the means killing moles posing a grave threat to our hero. In contrast, in Reksio the dog and its master watch the popular bedtime story for children - See Reksio Watches the TV, 1972, dir. E. Wątor, mus. Z. Kowalowski). 
has an ear for music and we may assume that this time he should become a musician ${ }^{31}$ ). The young apprentice, uniterrupted, continues and exchanges the greetings with the dog (Reksio entered the room). However, he is upset when Reksio accompanies him and is irritated when he sings solo. He decides to literally thumb at Reksio's nose (tremolando of the minor second) and commands the dog to leave. For a short moment the non-diegetic music returns (two guitar accords to the accompaniment of the vibraphone; it is a kind of cadence referring to the half-tones heard while thumbing dog's nose) and the boy practices again. Reksio is not obedient and remains in the room - it is harder and harder because his master plays completely out of tune.

When Reksio once again sings clearly, the boy throws him out. Reksio sits under the window and accompanies the false notes (it is so unbearable experience that Reksio is convulsed). The notes from the falsely played gamut almost bury the dog. After the cadence of the flute Reksio finally feels insulted and, barking, leaves the place (his master hits him with a flower pot). Far away from the home yard, he enters the different musical world: in the neighbourhood a girl practices the piano, which is reflected in the different pitch of the instrument, in the different musical texture, and in much better performance. Despite the fact that the girl is a performer, she ceases to play to clap her hands at Reksio singing under her window (Reksio improvises a short counterpoint to finish of the piano phrase). As one can see now, Reksio is able to sing in a duet, too. He is, however, shy and cannot believe he raised an applause. Thus, he enters her home and his unfinished phrase is played by the clarinet. Now, for a moment, the dog and the girl practice together (she accompanies and the dog sings). The piece sung by Reksio is rhytmically simple and contains largely second to third movements (the themes of the boy, the girl and the dog are motivically interconnected and are all in 2/4 meter). The duet suggest also the power of music to reconcile, as the pigeons appear surrounded with the heart of flowers. But the idyllic mood quickly dwindles because in the next scene one can see the kennel again. The boy wants Reksio to leave the doghouse and to retrieve (despite the accompaniment of the guitar, the melody of the flute is so imbued with trills that the next complication is about to occur). After that passage, the music gains even more importance because it is the Reksio's song that may lead the boy to the girl's home (and to find his dog). For the next time Reksio sings to the piano accompaniment, but the musical piece is interrupted. The boy commands Reksio to return home (the same fragment to which the boy looked

31 According to Zenon Kowalowski, in that episode it was the biggest issue to play the false notes credibly. He said: "I conducted perfect musicians. How could they imitate the boy practicing the violin? I told them to play that fragment in a manner of a child who does not care about the pitch. The professional musicians turned out to be unable to do that. At last, we took and amateur who zealously wanted to show how good he is. And his false notes were brilliant. The professionals were not genuine, not credible - no matter how much they strove. Because in that case one should have try to play it but in vain. The professionals knew too much how to do it and they were only able to deliberately destroy the beauty, which was audible. After half a day somebody told that there is one man playing the violin who is eager to show us how he plays. And that man did the trick." The statement by the composer from the interview with the Author (8 December 2012, Katowice). 
for the dog in its kennel). Reksio obedietly retrieves the stick. But he is unwilling to do that again and instead chooses the role of the musician (Reksio disappears and the musical work for the piano and solo voice explains where he escaped). His master must then pull Reksio along to fight the dog's resistance (the clarinet phrase, typical of the kennel, becomes less regular and is performed more slowly; the single guitar glissandos imitate the paws of Reksio sliding at the ground). Reksio is then insulted and refuses retrieving despite his master's attempts (the conflict is illustrated by means of the flute phrase with trills - the main motif of that phrase is repeated in the progression, which raises the tension). Finally, the boy picks the dog up and takes home where he starts practicing the same melody (without the audible improvement). It is precisely the moment in which it turns out that the boy is jelous of his dog and therefore he tooks it from the girl. The boy wants Reksio to sing to his accompaniment (and imitates Reksio's manner of singing). But the dog leaps out through the window to avoid hearing the false notes. The boy is angry but he decides not to surrender (he hits the window-sill with his fists and the clarinet persistently repeats the half-tone; other instruments join it). The boy starts practicing the scale. The use of ascending progression reflects his improvement: he plays more and more fast and clear. The final scene of the episode underscores the importance of practicing the instrument. Reksio and the girl perform their vocal-instrumental cantilene. Then, the boy with the violin comes to the window and when they are about to finish their phrase he improvises a cadence and plays the melody that he practiced from the very beginning of the episode. This time he is able to play it clearly. Additionally, it seamlessly wreaths their composition. Afterwords, the boy plays a solo piece for the violin. Reksio and the girl appreciate it, ceasing to play. Reksio once again leaps through the window but this time to sing a new melody (somewhat resembling the previous piano piece). Its master accompanies it, quite professionally. Then, the girl starts a new motif that is more difficult. The violin soloist responds with beautiful glissandos and variations on the previous melody. He adds also some percussion effects striking the fence and watering can with his bow. He tap-dances. While playing, he is constantly running with his dog (which no longer sings but barks). In other words: practice makes perfect. The coda ends with the introduction of the narrative element into the music - the dialogue between the violin and the flute is a synthesis of the diegetic and non-diegetic music. The boy puts the violin away and hugs his dog, because the friendship is more important than the mastery.The musical conclusion is typical of many episodes of the series (the flute with the accompaniment - the last notes are played on the vibraphone). 
Fig. 4: Reksio as a Singer (Reksio śpiewak)

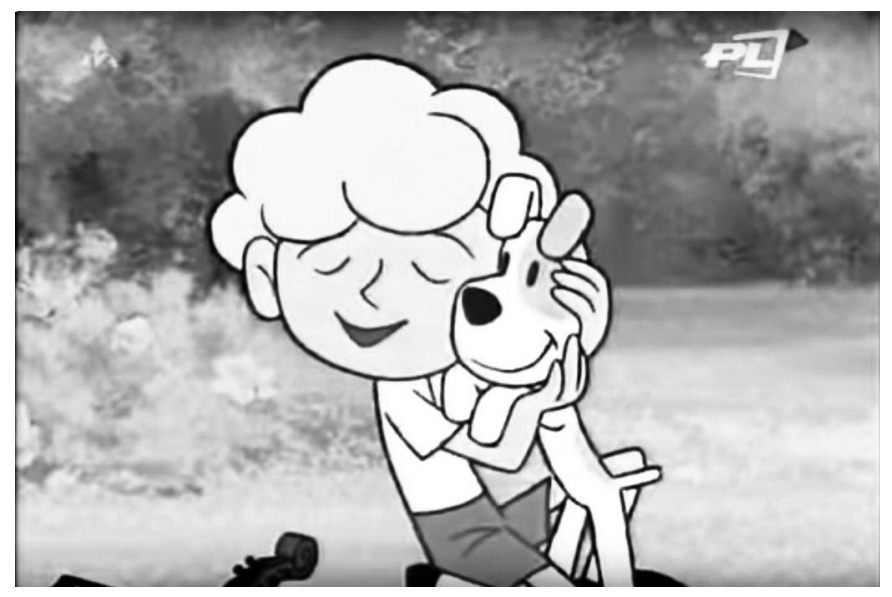

The issue of the singing dog is quite interesting. In other episodes Reksio only barks hoarsely. It is a suprise that he is an owner of pure and high-pitched voice. Moreover, he is not obliged to practice as his master. ${ }^{32}$

In the analyzed episode the composer wanted to use the parody and stylization to depict the real process of practicing the instrumental works. The characters are two children far from musical mastery and the episode is quasi-pedagogical with regard to the repertoire. Reksio as a Singer is similar to The Mole and the Music in its deeper message: it is an encouragement to play the music together in order to socialize with other people (music is one of the oldest and most basic occasions to do that and the composer wanted to show how natural it is - typical even for the animals). In both the Czech and Polish cartoon the main framework consists in presenting the musical material solo to join it together into symphonic or choral form at the end of the episode.

The comparison of the three pairs of the episodes from the cartoons produced about the same time and in the similar cultures shows how inventive were the composers and how many tools they finally used. Moreover, as stated Iwona Sowińska: "Through music film opens itself to the cultural (or even: civilization) context, in a way which is unique and worthy of attention [...]." ${ }^{33}$

Composers provided the cartoons for children with illustrative fragments, with more advanced symbolism rooted in the traditional musical topoi and also with the autonomous musical images referring to the imagination of the audience. The symbolic function is inherent not only in the orchestration but also in all the structural components of the music such as harmony, scale, meter or rhythm. Regarding the collaboration of the music and

\footnotetext{
32 Surprisingly, it was the composer who sang the role of Reksio (high register was obtained by means of accelerating the pace of the playback.

33 Sowińska, Polska muzyka filmowa 1945-1968, 11.
} 
visual layers, they used simple homology but also the advanced solutions stressing their mutual independence. The composers were technically well prepared and original. More importantly, they knew how to speak to the imagination and emotions of the children. Vadim Petrov said : "My music is close to children with their specific perception and sensitivity [...] People have liked the favorite music of their childhood all their lives. It should be a prize for the composer. Even the people who are in their fifties have liked the music to the cartoons, a memory from their salad days [...] The most crucial difference between the music for children and adults is that the former requires something with changing rhythm and clear musical inventions. The music for adults must, on the other hand, influence the recipients psychologically [...] Emotions in a good cartoon are expressed by means of the music and not by the visual background." ${ }^{34}$ According to Zenon Kowalowski: "[the music] should be, of course, ambitious, but its convention should speak to children and support the understanding of the content [...] One should not exagerrate with it [...] The music for adults may involve bigger orchestra, and more advanced texture and composing tools. But in the case of the music for children one ought not to hamper them the reception. If the composer uses too sophisticated means, the children will focus solely on the sounds and not on other values. Therefore, the sound and images and effects must be in balance [...] The composer must first know which value or meaning is of utmost importance in the particular episode and then - underscore it wuth the music." ${ }^{35}$

Translation: Piotr Plichta

\title{
In Search of Stylistic Idiom - Music to the Central-European Cartoons Krtek and Reksio
}

\begin{abstract}
This paper concerns the issue of music in two well-known twentieth-century series Czechoslovakian Krtek (aired between 1957 and 2002) and Polish Reksio (1967-1990). My aim was to present the wealth of composer's ideas - how they provided the films not only with illustrative fragments and interesting stylizations, but even with autonomous musical images. Soundtracks reveal excellent workshop of their authors, their originality and sense of humor. Sometimes we hear classical like music, another time it is even avant-garde. To show the similiarities and differences between artistic strategies (not only strictly musical) I choosed three pairs of cartoons (from both series) which action takes place in the similar surroundings or which refer to the suchlike questions. The article presents the conclusions from audiovisual analysis and therefore the description of music is inseparable from the plot. In the case of Krtek I present films with music of

34 The statement of the composer from the correspondence with the Author (January 2016).

35 The statement by the composer from the interview with the Author (8 December 2012, Katowice).
\end{abstract}


two composers - Miloš Vacek (1928-2012) and Vadim Petrov (1932), in case of Reksio it is one composer - Zenon Kowalowski (1939).

\title{
Hledání stylového idiomu - hudba ve středoevropských kreslených seriálech Krtek a Reksio
}

\begin{abstract}
Abstrakt
Příspěvek se zabývá hudbou k známým animovaným seriálům dvacátého století československému Krtkovi (vysílanému během let 1957 až 2002) a polskému seriálu Reksio (1967-1990). Cílem studie bylo představit bohatství hudebních myšlenek tvůrců hudebních doprovodů $\mathrm{k}$ zmíněným pořadům - jde nejenom o prvky hudebních ilustrací a stylizací, nýbrž také o autonomní hudební obrazy. Hudební doprovody ukazují invenci, originalitu i smysl pro humor svých tvůrců. Kombinují přístupy tradiční i avantgardní vážné hudby. S cílem ukázat podobnosti a rozdíly tvưrčích strategií (nejenom těch čistě hudebních) byly vybrány tři páry epizod (z obou seriálů), jejichž př́iběhy jsou zasazeny do podobného prostředí, př́ipadně mají shodné tematické soustředění. Závěry studie vycházejí z audiovizuální analýzy, přičemž reflexe hudby je vedena paralelně s popisem mimohudebních dějů. V př́padě seriálu Krtek je prezentována hudba dvou skladatelů Miloše Vacka (1928-2012) a Vadima Petrova (1932), v př́ípadě seriálu Reksio jde o jednoho skladatele - Zenona Kowalowského (1939).
\end{abstract}

\section{Keywords}

Music and animation; music to the Central-European cartoons; music to the Krtek; music to the Reksio; Miloš Vacek; Vadim Petrov; Zenon Kowalowski.

\section{Klíčová slova}

Hudba a animace; hudba k středoevropským animovaným seriálům; hudba k seriálu Krtek; hudba k seriálu Reksio; Miloš Vacek; Vadim Petrov; Zenon Kowalowski. 